\title{
Impact of Human Capital Underutilization on Economic Growth: the Case of India
}

Vijaya Kumar M ( $\square$ mail4vijay97@gmail.com )

University of Kerala

\section{Balu B}

University of Kerala

\section{Research Article}

Keywords: Human capital, Underutilization, Economic growth, Education, India

Posted Date: November 19th, 2021

DOI: https://doi.org/10.21203/rs.3.rs-914304/v2

License: (c) (i) This work is licensed under a Creative Commons Attribution 4.0 International License. Read Full License 


\title{
Impact of Human Capital Underutilization on Economic Growth: the Case of India
}

\author{
Vijaya Kumar M.* (Corresponding Author), Balu B. (Co-author) \\ ${ }^{1}$ Department of Commerce, University of Kerala, \\ Email-mail4vijay97@gmail.com \\ Postal Address- Department of Commerce, \\ University of Kerala, Thiruvananthapuram, PIN: 695581, Kerala, India \\ ${ }^{2}$ School of Distance Education, University of Kerala, \\ Email-bbalub@gmail.com
}

\begin{abstract}
This study investigated the effect of human capital underutilization on the economic growth of India. It has used time-series data accessed from the International Labor Organization (ILO) and World Bank database. This paper estimated the relationship between the underutilization of human capital on economic growth by applying the econometric tests like Augmented Dickey-Fuller (ADF) Test, Johansen Integration Test, and the Autoregressive Distributed Lag (ARDL) model. The results revealed that in the long run human capital underutilization has a negative relationship on GDP and labor productivity and it does not in the short run. The study recommends that specific policy legislations in the Indian labor markets are required for addressing the problem of human capital underutilization and thereby accelerating the economic growth and productivity for the current and future generations.
\end{abstract}

Keywords Human capital. Underutilization . Economic growth . Education . India

\section{Introduction}

India has witnessed an accelerated GDP growth rate trend during the last decades since the early1980s and this was further strengthened after the 1990s due to the introduction of new economic reforms. Resilence is considered a remarkable feature of India's growth story. But paradoxically it is said that the rapid growth has not transformed the labor market and employment conditions in India. All indicators show that a wide range of disparities are not being addressed properly and there is a strong urge for inclusive growth. It means that all people are benefited from the process of growth. The labor market in India is enriched with a sizable proportion of its workforce. The total workers in India account for about one-sixth of 
the total workforce in the world. The unique characteristics of the nation like the demographic dividend in the young population and the geographical advantage make India stand strong among the world economies. As far as a country is concerned maintaining sustainable economic growth and development is a major challenge to reserve prosperity. One of the pertinent issues faced by developing countries is the underutilization of human capital and it is detrimental to the economic growth and development of a nation. (UIA, 1997) identified human capital underutilization as the world problem or global issue of all developing and developed countries in the world. Even though the unemployment rate is considered a measure of labor underutilization, it does describe everything about human capital underutilization. So eliminating unemployment is not enough to curb the problem of human capital underutilization. There are other types of labor underutilization in existence.

Education has a significant impact on increasing the economic growth and productivity of a nation (Tsamadias \& Prontzas, 2012a). and its utilization depends on the aspects of the demand-supply of the labor force. Human capital underutilization is happening when there is a mismatch between labor supply and labor demand (Hashem, 2021), and it is due to the abundant supply of laborers or underutilization of their qualifications and skills or workers does not get enough working hours to work otherwise called time-related underemployment. As per the three-year action agenda of Niti Aayog opined that India is facing a serious problem of severe underemployment than unemployment. As per the qualitative terms, overqualification is also considered a factor of labor underutilization and it is a common issue in all labor markets. This research aims to estimate the relationship between different types of human capital underutilization and its impact on economic growth in India for the 2005-2019 period.

\section{Review of Literature}

As per the credence of the theoretical view, human capital is positively related to economic growth. (Ali et al., 2018) has conducted a study to validate the empirical aspects of human capital and how it is positively associated with economic growth. For this study, they had been surveyed 132 countries over 15 years and the study results reveal that human capital has a positive association with economic growth provided there exists a presence of high-quality legal institutions and better economic opportunities.

A study conducted by (Viswanath et al., 2017) on human capital contributions to economic growth in India based on aggregate production function analysis. They have employed crosssection data relating to the years 1995-96 and 1998-99 of 26 Indian states and union 
territories to estimate the contributions of physical and human capital to economic growth. The results of the study reveal the existence of a strong positive relationship between human capital and economic growth. Nauriyal et al., (2009) revealed that post-liberalization had brought an increase in the share of human capital over physical capital that India's share of human capital, and it has a significant impact on the economic growth of the nation.

Regarding the education and economic growth in the context of India (Schündeln \& Playforth, 2014) had found that the contribution of education to economic growth has a dynamic improvement in the economic performance of the country since 1980. (Self \& Grabowski, 2004) proved that primary education in India has a strong and causal effect on economic growth.

(Curea \& Ciora, 2013) investigated the relationship between human capital and economic growth and analyzed the presence of human capital in macroeconomic growth models. (Garza-Rodriguez et al., 2020) estimated the relationship between human capital and economic growth in the context of Mexico. They found that human capital has a significant impact on economic growth over physical capital.

Tsamadias \& Prontzas, (2012a) empirically tested the interaction between the distribution of human capital, economic growth, and technological progress, (Tsamadias \& Prontzas, 2012a) also done a comparative study of Pakistan and India, and the results revealed that human capital has a positive impact on economic growth.

Using a theoretical macroeconomic model (Doppelt, 2019) investigated and established a linkage with long-run economic growth and labor market dynamics. He found that unemployment has negatively impacted economic growth and hindered further skill formation.

Recently (Hashem, 2021) estimated the effects of human capital underutilization on the economic growth and productivity in Egypt. He has used various econometric techniques to analyze the time-series data from the period of 1991 to 2019. The study finding says that human capital underutilization has a long-term impact on economic growth in Egypt, but it does not in the short run. The study found that Egypt has a weak link between education output and the requirements of the labor market.

The previous literature confirms that human capital has a significant and positive impact on economic growth in the context of India. But there are lacking studies to estimate the relationship between the underutilization of human capital and economic growth. 


\section{Okun's law and its validity in India}

Okun's law refers to the relationship between aggregate output and the unemployment of an economy. According to Okun's law, a shift in aggregate demand causes aggregate output to fluctuate around the potential. This leads organizations to hire new employees and the resulting employment rate shift in the opposite direction. A study conducted by (Bhat, 2019) to assess the validity of Okun's Law in India revealed that there is a negative relationship between economic growth and the unemployment rate in India. Their model suggests that a 1 percent increase in GDP will decrease the unemployment rate by 0.4 percent. Kim et al., (2020) and (Hashmi et al., 2021) empirically validated Okun's law in the context of India. Unemployment is considered as a measure of labor underutilization and a significant decline in the rate of unemployment will have a direct and positive impact on the aggregate level of output and productivity.

$\mathrm{Et}-\mathrm{Et}^{*}=\gamma\left(\mathrm{Yt}-\mathrm{Yt}{ }^{*}\right)+\eta \mathrm{t}, \gamma>0 ;$
$\mathrm{Ut}-\mathrm{Ut}^{*}=\delta(\mathrm{Et}-\mathrm{Et} *)+\mu \mathrm{t}, \delta<0 ;$

Where;

$\mathrm{Et}=\log$ of employment

$\mathrm{Yt}=\log$ of output

$\mathrm{Ut}=$ unemployment rate

$*$ = long-run level

Now the Okun's Law can be derived by substituting (1) into (2):

$\mathrm{Ut}-\mathrm{Ut}^{*}=\beta(\mathrm{Yt}-\mathrm{Yt} *)+\varepsilon \mathrm{t}, \beta<0$

where $\beta=\gamma \delta$ and $\varepsilon t=\mu t+\delta \eta t$. The coefficient $\beta$ in Okun's Law depends on the coefficients in the two relationships that are fundamental to the Law (Ball et al., 2013).

\section{Human Capital in India}

Human capital comprises of educational, health, and other competencies of an individual which are intangible and can be used for a long period. Human capital has the potential to increase countries' productivity and economic growth. Human Capital Index (HCI) is the index of the World Bank that measures the potential productivity of a country. The overall value of HCI in India for 2020 is 0.49 . 
Table $1 \mathrm{HCI}$ in India 2020

\begin{tabular}{llll}
\hline Indicators & Boys & Girls & Overall \\
\hline HCI & 0.49 & 0.50 & 0.49 \\
Survival to Age & 0.96 & 0.96 & 0.96 \\
Expected Years of School & 11.0 & 11.2 & 11.1 \\
Harmonised Test Scores & 399 & 399 & 399 \\
Learning Adjust Years of School & 7.1 & 7.2 & 7.01 \\
Adult Survival Rate & 0.80 & 0.85 & 0.83 \\
Not Stunted Rate & 0.65 & 0.66 & 0.65 \\
HCI Ratio (richest/ poorest 20 & & & 1.39 \\
percent) & & &
\end{tabular}

Source: World Bank Database

It indicates that a child born in India today will be only 49 percent as productive when he grows up as he could be benefited the full health and complete education. The HCI value of higher than for the South Asia region and other lower-income Countries (World Bank, 2020). In last year, India had ranked $116^{\text {th }}$ position among the 157 countries in the world.

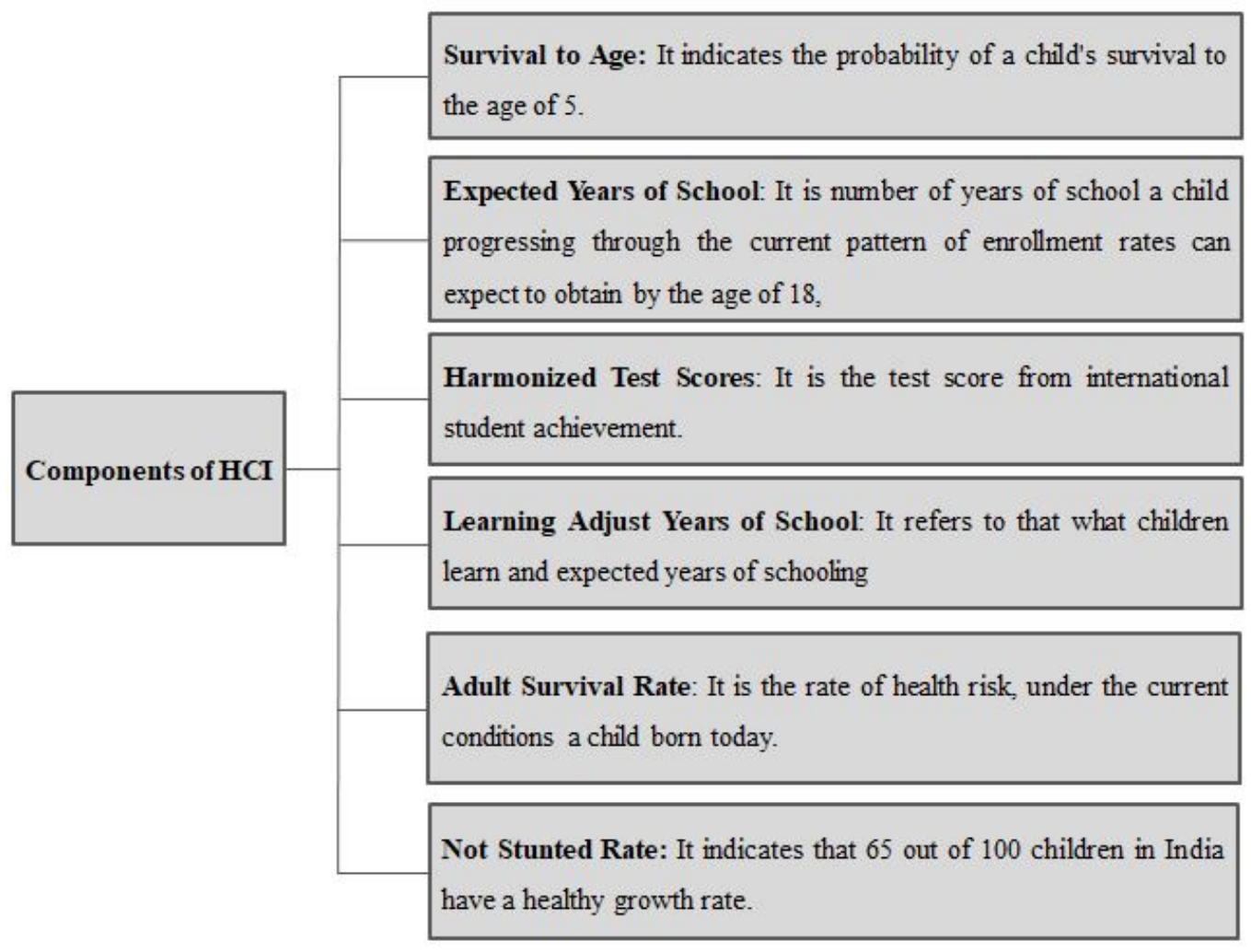

Fig. 1 Components of Human Capital Index 


\section{Measurements of Human Capital and the Utilization of Adjusted Human Capital Index}

(UHCI)

The Human Capital Index (HCI) measures how the outcomes of current health and education conditions prevailing in a country influence the upcoming generations' labor productivity. The Human Capital Index components are combined into a single index by converting them into contributions to productivity (world bank group, 2020).

HCI $=$ Survival $\times$ School $\times$ Health

Survival $=\frac{1-\text { under } 5 \text { mortality rate }}{1}$

School $=\mathrm{e}^{\varnothing}\left(\right.$ expected years of school $\left.\times \frac{\text { Harmonized test score }}{625}-14\right)$

Health $=\mathrm{e}\left(\gamma_{\mathrm{ASR}}(\right.$ Adult survival rate -1$)+\gamma_{\text {stunting }} \times($ not stunded rate -1$) / 2$

The resulting index has values that lie between 0 and 1 . So a score of 0.75 indicates that a child born in today's productivity is 25 percent lower than could be attained by complete education and health.

The Human Capital Index (HCI) indicates the quantum of human capital expected to accumulate by a child when he attains the age of 18 , considering the current education and health condition in the country. It also helps to assess how changes in education and health influence the productivity of workers in the upcoming generation. A child born in a country is expected to grow up and becomes a future worker and assumes that he will find suitable work. It is said to be incorrect that a sizable proportion of the population in developing countries are unemployed/ working in jobs that do not allow them to utilize their full skill and potential. The effective utilization of adjusted human capital will rectify the problem of underutilization of human capital in labor markets. The working-age population should effectively utilize their skills, abilities, education, and another potential to enhance productivity. So the UHCI is supplementary measures of HCI are;

UHCI $($ basic or full $)=$ Utilization rate $($ basic or full $) \times \mathrm{HCI}$

Basic UHCI = Income gains of potential [Unemployed] workers

Full UHCI $=$ Increased employment rate + Gains from relocating workers to locations 
Utilization (Basic measure) $=\frac{\text { Employment }}{\text { Working Age Population }}$

Utilization $($ Full measure $)=$ BER $\times 1+(1-$ BER $) \times \frac{\text { Minimum HCI }}{\text { HCI }}$

BER $($ Better Employment Rate $)=\frac{\text { Non }- \text { agriculture wage employees }+ \text { Employers }}{\text { Population working age }}$

UHCI $($ Full measure $)=$ BER $\times$ HCI $+(1-$ BER $) \times($ Minimum HCI $)$

The world bank analyzed the HCI utilization measures for more than 160 countries and discovered that GDP per capita will be $\frac{1}{\mathrm{UHCI}}$ higher in a sphere of complete utilization of education can health (Akyüz, 2017).

\section{Problems of Human Capital in India}

Human capital has a significant role in the creation and development of aggregate economic growth in the country. Improving human capital will help to reduce poverty and foster the welfare of the people as a long-term goal. But it has many challenges to address at the general level.

Table 2 Unemployment in India (2004-2019)

\begin{tabular}{lllll}
\hline Indicators & 2004 & 2009 & 2014 & 2019 \\
\hline Total Unemployment Rate (\%) & 5.72 & 5.61 & 5.6 & 5.27 \\
Male & 5.72 & 5.59 & 5.6 & 5.28 \\
Female & 5.71 & 5.67 & 5.63 & 5.21 \\
\hline
\end{tabular}

Source (ILO, 2021a)

- In India, the Unemployment rate has shown a continuous decrease from 5.72 percent in 2004 to 5.24 percent in 2019.

- Even though the female unemployment rate in India is higher compared to males, both values had shown a decreasing trend from 2004 to 2019. 


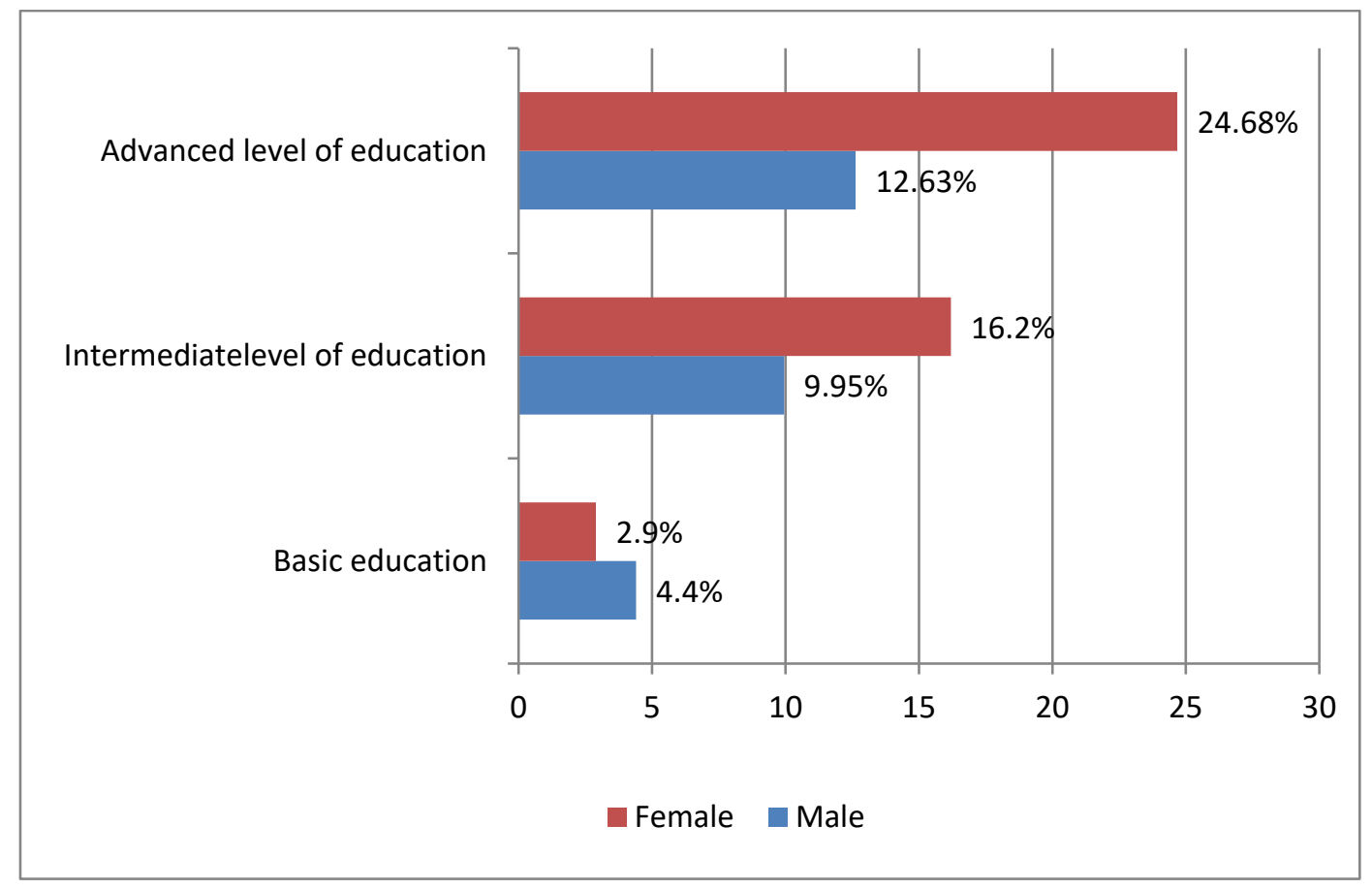

Fig. 2 Distribution of unemployed by level of education and sex in India in 2018 (Source: ((Statista, 2021))

- In India majority of the females with an advanced level of education are unemployed and account for 24.68 percent of the aggregate population, and the male population with the percentage of 12.63 .

- In the case of intermediate level of education, 16.2 percent of the female population and 9.95 percent of the population in India are unemployed.

- In the case of basic education in India, females are less unemployed 2.9 percent compared to the males with 4.4 percent.

- The report published by (Statista Research Department, 2021) revealed that graduate has the highest share of 16.3 percent of unemployment and the budget estimates by the Indian government also say that there has been a deficit in the estimates of the actual number of jobs created compared to the real jobs created over years.

\section{Human capital Underutilization}

The unemployment rate is considered as a measure of labor underutilization, but it has limited to a specific population ignoring those who are employed and those who are outside the labor force. Being the unemployment rate is only a component of labor underutilization the Nineteenth International Conference of Labor Statisticians (ICLS) has introduced the four measures of labor underutilization (Gammarano \& Mathys, 2018). 
Indicators to measure labor underutilization (Gammarano \& Mathys, 2018).

LU1 - Unemployment rate $=\frac{\text { Unemployment }}{\text { Labour force }} \times 100$

LU2 - The combined rate of time - related underemployment and unemployment

$$
=\frac{\text { Time }- \text { related underemployment }+ \text { Unemployment }}{\text { Labour force }} \times 100
$$

Time-related underemployment can be defined as the category of employees who want to work for more hours if they have been allowed to work.

LU3 - The combined rate of unemployment and Potential labor force

$$
=\frac{\text { Unemployment }+ \text { Potential labour force }}{\text { Labor force }+ \text { Potential labour force }} \times 100
$$

The potential labor force is the category of the labor force in which they are actively searching for jobs or will enter the labor market shortly.

LU4 - Composite measure of labor underutilization

$$
=\frac{\text { Time }- \text { related underemployment }+ \text { Potential labour force }}{\text { Labor force }+ \text { Potential labour force }} \times 100
$$

Table 3 Labor Underutilization in India (2010-2019)

\begin{tabular}{llll}
\hline Year & LU2 & LU3 & LU4 \\
\hline 2010 & 8.9 & 6.8 & 10 \\
2011 & 8.8 & 6.8 & 9.9 \\
2012 & 8.7 & 6.8 & 9.9 \\
2013 & 8.7 & 6.9 & 9.9 \\
2014 & 8.6 & 6.8 & 9.8 \\
2015 & 8.5 & 6.8 & 9.7 \\
2016 & 8.4 & 6.8 & 9.6 \\
2017 & 8.3 & 6.7 & 9.5 \\
2018 & 8.2 & 6.7 & 9.5 \\
2019 & 8.1 & 6.6 & 9.4 \\
\hline Sourc:(ILO $012021 b)$ & & & \\
\hline
\end{tabular}

Source:(ILO, 2021b) 
- The Combined rate of time-related underemployment and unemployment in LU2 of India decreased from 8.9 percent in 2010 to 8.1 percent in 2019.

- For LU2, we found that youth labor underutilization (15-24) LU2 was high 25.8 percent in 2019. It increased between 2010 and 2019 (From 24 to 25.8 percent). Youth labor underutilization was particularly high among young women. In 2019, female labor underutilization LU2 26.8 percent. Although it was 25.6 percent among males.

- In terms of geographical coverage of disparities in labor underutilization, the rate in urban areas is higher than that of rural areas, and it accounts for 9 percent in urban areas and 7.7 percent in rural areas in the year 2019.

- The combined rate of unemployment and Potential labor force LU3 of India decreased from 6.8 percent in 2010 to 6.6 percent in 2020

- In 2019, Youth labor underutilization (15-24) was 27.1 percent for LU3. It grew between 2010 and 2019 (23.2 to 27.1 percent. Female youth labor underutilization was higher compared to male youth underutilization.

- In 2019, the female had an LU2 of 29.2 percent, while males had an LU2 of 26.6 percent. We also discovered that the LU3 rate was low in the high age group (25+), with 3.2 percent in 2010 and 3 percent in 2019.

- The composite rate of labor underutilization in LU4 decreased from 10 percent in 2010 to 9.4 percent in 2019.

- In terms of geographical coverage of disparities in labor underutilization, the rate in urban areas is higher than that of rural areas, and it accounts for 10.4 percent in urban areas and 8.9 percent in rural areas in 2019.

- The youth labor underutilization (15-24) LU4 in 2019 was 29.7 percent [31.4 percent for females and 29.4 percent for males].

- We also discovered that the LU4 rate was constant in the high age group (25+), with 6 percent in 2010 and 2019.

- LU4 for females was 8.4 percent in 2019 [13.4 percent in urban and 6.4 percent in rural], and the LU4 youth females increased from 28.3 percent in 2010 to 31.4 in 2019. 


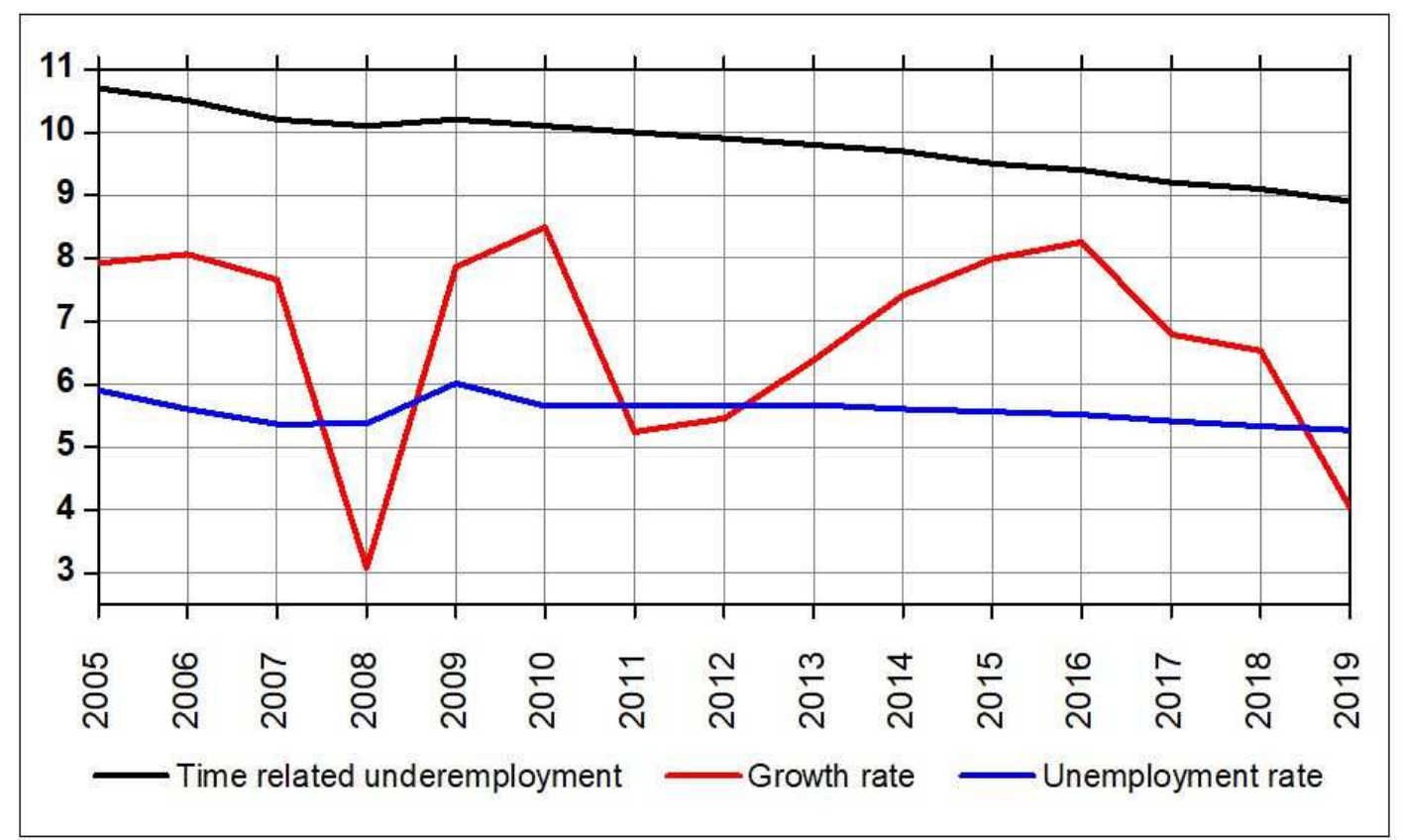

Fig. 3: Relationship between labor underutilization and economic growth in India (20052019) (Source: (World Bank, 2021) and (ILO, 2021b))

It is important to note that the economic growth in India fluctuates over time from 2005 to 2019. During 2008 the world has witnessed the great depression and it has adversely affected the Indian economy and the GDP has crippled to 3.08 percent during the year. After that, a remarkable recovery had brought out and a hike of GDP to 7.86 in 2010. It remains stagnant in 2010 and again decreased to 5.24 percent in the year 2011. In 2016 the real economic growth attained the highest values in 2010 and 2016 with a percentage of 8.49 and 8.25 respectively. After 2016, it has shown a downward trend and reduced to 4.04 percentage in 2019. It is due to various policy agendas of government like demonetization of currency, tax reforms, and also due to the collapse in private consumption.

Unemployment is considered an indicator of labor underutilization. In India, the unemployment rate was consistent during 2010-2011, then it started fluctuating through years and showed a downward slope from 2015 to 2019. But as per the latest data of (World Bank, 2021), the unemployment rate in India has increased to 7.11 percent in 2020 which is a record hike compared to the last decade. This is due to the outbreak of the Covid 19 pandemic that also hurts the global economy. The unemployment of the total workforce in India was at 5.27 percent in 2019, which was a less percentage compared to the previous year. So it can be inferred that India was successfully implementing measures to abolish the unemployment scenario and this might be interrupted due to the outbreak of the Covid-19 pandemic. 


\section{Data and Methodology}

The current study is based on the annual time series data from 2005 to 2019 and has been collected from the International Labor Organization (ILO) and World Bank database. The applied econometric techniques like Augmented Dickey-Fuller (ADF) Test, Johansen Integration Test, and the Autoregressive Distributed Lag (ARDL) model were used to estimate the relationship between the human capital underutilization on economic growth (GDP) and to analyze the causal relationship that exists among these variables.

\section{Augmented Dickey-Fuller (ADF) Test}

The purpose of this study is to know if there is a link between the underutilization of human capital. There are various tests, one of the commonly used to test the unit root in time series data is the Augmented Dickey-Fuller (ADF) Test (Tsamadias \& Prontzas, 2012b).

\section{Johansen Test for Cointegration}

We have adopted the ARDL model for bounds testing of cointegration formulated by (Pesaran et al., 2001). The test is used to find the presence long-run relationship between the observed variables.

\section{ARDL model}

An Auto-Regressive Distributed Lag Model (ARDL) uses the lags of dependent variables and the lagged values of independent variables (Ghosh, 2009), by employing the ARDL model the short-run and long-run effect can be directly and indirectly estimated respectively. Variables are found integrated in mixed order that is four variables are stationary in the first difference and the other one is stationary at level. Then we can use the ARDL model.

\section{Empirical Analysis and Results}

\section{Unit Root Tests}

The initial step is to determine if the time series data are stationary or non-stationary. That is the time series data has unit root or not.

Table 5 Augmented Dickey-Fuller Test

\begin{tabular}{lllllll}
\hline Variable & \multicolumn{3}{c}{ Level } & \multicolumn{3}{c}{ First Difference } \\
\cline { 2 - 7 } & Intercept & $\begin{array}{l}\text { Intercept \& } \\
\text { Trend }\end{array}$ & None & Intercept & $\begin{array}{l}\text { Intercept \& } \\
\text { Trend }\end{array}$ & None \\
\cline { 2 - 7 } & -3.102 & -2.998 & -0.974 & -4.313 & -4.110 & -4.426 \\
GDP & $(0.049)^{*}$ & $(0.016)^{*}$ & $(0.279)$ & $(0.006)^{* *}$ & $(0.032)^{*}$ & $(0.000)^{*}$ \\
\hline
\end{tabular}




\begin{tabular}{lllllll} 
& -2.624 & -2.873 & -0.808 & -4.358 & -4.184 & -4.470 \\
& & & & & & \\
& $(0.111)$ & $(0.198)$ & $(0.347)$ & $(0.006)^{* *}$ & $(0.029)^{*}$ & $\begin{array}{l}(0.000)^{*} \\
* *\end{array}$ \\
\cline { 2 - 6 } & & & & & -3.769 & -3.911
\end{tabular}

EAG

\begin{tabular}{llllll} 
& & & & $* *$ \\
\hline-2.624 & -2.873 & -0.808 & -4.358 & -4.184 & -4.470
\end{tabular}

\begin{tabular}{llllll}
$(0.366)$ & $(0.667)$ & $(0.689)$ & $(0.015)^{*}$ & $(0.048)^{*}$ & $\begin{array}{l}(0.000)^{*} \\
* *\end{array}$ \\
\hline-3.522 & -3.356 & -0.784 & -4.572 & -4.406 & -4.735
\end{tabular}

LP

\begin{tabular}{llllll}
$(0.023) *$ & $(0.097)$ & $(0.358)$ & $(0.004) * *$ & $(0.020)^{*}$ & $\begin{array}{l}(0.000)^{*} \\
* *\end{array}$ \\
\hline-0.097 & -1.654 & -5.261 & -3.412 & -9.536 & -1.455
\end{tabular}

TU
$(0.931)$
$(0.716)$
$(0.000)^{* * *}$
$(0.032)^{*}$
$(0.000) * * *$
$(0.000)^{*}$
**

GDP- Gross Domestic Product, UR- Unemployment Rate, EAG- Employment in Agriculture, LP- Labor Productivity, TU- Time Related Underemployment

From table 5, we can say that with using 0.05 level of significance level GDP is stationary at level, while all other variables are stationary at first difference.

\section{Johansen Cointegration Test}

It is used to find the trace test and maximum Eigenvalue to find the presence long-run relationship between the variables GDP, UR, EAG, LP, and TU.

Table 6 Johansen cointegration test (Trace and Maximum eigenvalue)

\begin{tabular}{llllll}
\hline $\begin{array}{l}\text { Hypothesised No. of } \\
\text { CE }\end{array}$ & $\begin{array}{l}\text { Eigen } \\
\text { value }\end{array}$ & Trace test & $\begin{array}{l}\text { P-value } \\
* *\end{array}$ & $\begin{array}{l}\text { Max-Eigen } \\
\text { Statistic }\end{array}$ & $\begin{array}{l}\text { P-value } \\
* *\end{array}$ \\
\hline None ${ }^{*}$ & 0.99170 & 129.16 & 0.0000 & 67.089 & 0.0000 \\
At most $1 *$ & 0.93177 & 62.074 & 0.0010 & 37.588 & 0.0011 \\
At most 2 & 0.73341 & 24.486 & 0.1865 & 18.508 & 0.1143 \\
At most 3 & 0.34057 & 5.9771 & 0.7012 & 5.8294 & 0.6404 \\
At most 4 & 0.010499 & 0.14776 & 0.7007 & 0.14776 & 0.7007 \\
\hline
\end{tabular}

Table 6 shows the results of the Johansen test for the trace test and maximum Eigenvalue, the results reveal that at the 0.05 level of significance there are two co-integrating egn(s). So the findings confirm the presence of long- term relationship between those variables. 


\section{ARDL Model}

Table 7 ARDL model estimates for GDP

\begin{tabular}{llll}
\hline Variable & Coefficient & t-Statistic & P Value** \\
\hline GDP(-1) & -0.574787 & -1.462811 & 0.2397 \\
GDP(-2) & -0.313045 & -3.251823 & 0.0474 \\
LP & 1.199969 & 16.94667 & 0.0004 \\
LP(-1) & 0.650510 & 1.369039 & 0.2645 \\
TU & 3.072639 & 1.659123 & 0.1957 \\
TU(-1) & -3.202499 & -1.997912 & 0.1396 \\
EAG & -0.120203 & -2.508106 & 0.0871 \\
EAG(-1) & 0.085724 & 3.067444 & 0.0547 \\
UR & -2.589599 & -1.825402 & 0.1654 \\
C & 19.18778 & 3.865473 & 0.0306 \\
R-squared & 0.995694 & & \\
Adjusted R-squared & 0.982778 & & \\
S.E. of regression & 0.220148 & & \\
Sum squared resid. & 0.145395 & & \\
Log-likelihood & 10.75992 & & \\
F-statistic & 77.08551 & & \\
Prob. (F-statistic) & 0.002173 & & \\
\hline
\end{tabular}

ARDL model estimates reveal that GDP is significantly positively affected by labor productivity only. Table 8 indicates that over the long run if time-related underemployment decreases by 1 percent GDP will significantly increase by 3.2 percent. Also, if the unemployment rate decreases by 1 percent GDP will increase by 2.58 percent. Employment in agriculture decreased by 1 percent and labor will choose industry or service sector will increase GDP 0.085 percent (but this is insignificant).

Table 8 F- Bounds test

\begin{tabular}{lllll}
\hline Test Statistic & Value & Significance & $\mathrm{I}(0)$ & $\mathrm{I}(1)$ \\
\hline F-statistic & 5.869218 & $10 \%$ & 2.45 & 3.52 \\
$\mathrm{k}$ & 4 & $5 \%$ & 2.86 & 4.01 \\
& & $2.5 \%$ & 3.25 & 4.49 \\
& $1 \%$ & 3.74 & 5.06 \\
\hline
\end{tabular}


The cointegration test results here indicate that F- statistic value is 5.869218 , it is greater than the lower bound and upper bound at 5 percent level of significance, it shows that there is a long-run equilibrium relationship between GDP (Dependent variable) and Labor productivity, Time related underemployment and Employment in agriculture (Independent variables).

Table 9 ECM regression for GDP

\begin{tabular}{llll}
\hline Variable & Coefficient & t-Statistic & P Value** \\
\hline C & 19.18778 & 8.282217 & 0.0037 \\
D(GDP(-1)) & 0.313045 & 6.268172 & 0.0082 \\
D(LP) & 1.199969 & 37.80160 & 0.0000 \\
D(TU) & 3.072639 & 4.455564 & 0.0210 \\
D(EAG) & -0.120203 & -5.827519 & 0.0101 \\
CointEq(-1)* & -1.887832 & -8.274915 & 0.0037 \\
\hline
\end{tabular}

Table 9 shows the short-run ARDL results of GDP on its independent variables. The value of cointegration is -1.887832 , it is statistically significant and less than zero, less than -1 and greater than -2 , it means that moving from the short run to the long run the system will oscillate above and below the equilibrium value in a diminishing nature until it reaches to the equilibrium path. The results also reveal that there is no significant effect of the unemployment rate on GDP.

Table 10 ARDL long run form and bounds test

\begin{tabular}{llll}
\hline Variable & Coefficient & t-Statistic & P Value \\
\hline LP & 0.980214 & 17.84084 & 0.0004 \\
TU & -0.068788 & -0.303025 & 0.7817 \\
EAG & -0.018264 & -1.211863 & 0.3123 \\
UR & -1.371732 & -1.518161 & 0.2263 \\
\hline
\end{tabular}

Table 10 shows the result of the ARDL long-run form and bounds test. It indicates that the Labor productivity (LP) is the only variable with statistical significance as it lies in the cut off of 0.05 level of significance, so it can be inferred that in the long run labor productivity has a significant positive relationship with GDP and all the other variables has a negative relationship with GDP. 


\section{Conclusions}

This paper examines the effects of human capital underutilization on the economic growth of India. The study employed the annual time-series data from 2005 to 2019 . The findings of the study revealed that moving from short run to long run the effect of human capital underutilization on GDP will oscillate above and below the equilibrium value in a diminishing nature until it reaches the equilibrium path. The results also revealed that in the short-run there is no statistically significant effect of the unemployment rate on GDP. But in the long run, human capital underutilization has a negative relationship with GDP. Cairó \& Cajner, (2018) argued that educated workers have more employment stability compared to lower education groups, but our findings go against this argument, one of the main challenges faced by India is the problem of severe skill-related youth underemployment. The majority of the youngsters have attained an advanced level of education; still there exists a problem of labor underutilization and underemployment in India.

So there is a strong urge for specific policy measures in Indian labor markets is required for address the problem of human capital underutilization and thereby accelerate economic growth and labor productivity. Generation of productive and skill-oriented job opportunities for the future labor force and proper training for the existing labor force is a feasible option for curtailing human capital underutilization in India. The long-run effect of human capital underutilization on GDP is specifically addressed as a major concern for India as the human capital of a nation is considered a vital tool for achieving social, economic, and political goals. As far as India is concerned it has a strong feature of demographic dividend and the potential of the younger population should effectively be utilized to reduce the issue of human capital underutilization.

\section{References}

Akyüz, Y. (2017). Global Economic Prospects: In The Financial Crisis and the Global South (Issue June). https://doi.org/10.2307/j.ctt183pb3w.5

Ali, M., Egbetokun, A., \& Memon, M. H. (2018). Human capital, social capabilities and economic growth. Economies, 6(1), 1-18. https://doi.org/10.3390/economies6010002

Ball, L. M., Leigh, D., Loungani, P., \& Al., E. (2013). Okun's Law: Fit at 50? In IMF Working Papers (Vol. 13, Issue 10). https://doi.org/10.5089/9781475574265.001

Bhat, T. A. (2019). The validity of Okun's Law: Evidences from Indian economy. Theoretical and Applied Economics, XXVI(4), 273-278.

Cairó, I., \& Cajner, T. (2018). Human Capital and Unemployment Dynamics: Why More 
Educated Workers Enjoy Greater Employment Stability. Economic Journal, 128(609), 652-682. https://doi.org/10.1111/ecoj.12441

Curea, Ş. C., \& Ciora, C. (2013). The impact of human capital on economic growth. Quality Access to Success, 14(SUPPL. 1), 395-399. https://doi.org/10.1016/s22125671(15)00258-0

Doppelt, R. (2019). Skill flows: A theory of human capital and unemployment. Review of Economic Dynamics, 31(December), 84-122. https://doi.org/10.1016/j.red.2018.12.004

Gammarano, R., \& Mathys, Q. (2018). Spotlight on Work Statistics: Avoiding unemployment is not enough (Issue August). https://www.ilo.org/global/statistics-anddatabases/publications/WCMS_644467/lang--en/index.htm

Garza-Rodriguez, J., Almeida-Velasco, N., Gonzalez-Morales, S., \& Leal-Ornelas, A. P. (2020). The Impact of Human Capital on Economic Growth: the Case of Mexico. Journal of the Knowledge Economy, 11, 660-675.

Ghosh, S. (2009). Electricity supply, employment and real GDP in India: evidence from cointegration and Granger-causality tests. Energy Policy, 37(8), 2926-2929. https://doi.org/10.1016/j.enpol.2009.03.022

Hashem, E. A. (2021). The Impact of Human Capital Underutilization on Productivity and Economic Growth in Egypt. Journal of Economics and Business, 4(2), 231-244. https://doi.org/10.31014/aior.1992.04.02.359

Hashmi, S. M., Khushik, A. G., Gilal, M. A., \& Yongliang, Z. (2021). The Impact of GDP and Its Expenditure Components on Unemployment Within BRICS Countries: Evidence of Okun's Law From Aggregate and Disaggregated Approaches. SAGE Open, 11(2). https://doi.org/10.1177/21582440211023423

ILO. (2021a). Unemployment, male (\% of male labor force) (modeled ILO estimate) - India | Data. World Bank. https://data.worldbank.org/indicator/SL.UEM.TOTL.MA.ZS?locations=IN

ILO. (2021b). Unemployment and labour underutilization - ILOSTAT. ILOSTAT. https://ilostat.ilo.org/topics/unemployment-and-labour-underutilization/

Kim, J., Yoon, J. C., \& Jei, S. Y. (2020). An empirical analysis of Okun's laws in ASEAN using time-varying parameter model. Physica A: Statistical Mechanics and Its Applications, 540, 123068. https://doi.org/10.1016/j.physa.2019.123068

Nauriyal, D. K., Sahoo, B. K., \& Dixit, A. (2009). Economic Growth, Globalisation and Human Capital: Empirical Evidence from India. The Indian Economic Journal, 56(4), 37-54. https://doi.org/10.1177/0019466220090404 
Pesaran, M. H., Shin, Y., \& Smith, R. J. (2001). Bounds testing approaches to the analysis of level relationships. Journal of Applied Econometrics, 16(3), 289-326. https://doi.org/10.1002/jae.616

Schündeln, M., \& Playforth, J. (2014). Private versus social returns to human capital: Education and economic growth in India. European Economic Review, 66, 266-283. https://doi.org/10.1016/j.euroecorev.2013.08.011

Self, S., \& Grabowski, R. (2004). Does education at all levels cause growth? India, a case study. Economics of Education Review, 23(1), 47-55. https://doi.org/10.1016/S02727757(03)00045-1

Statista. (2021). Unemployment with advanced education (\% of total labor force with advanced education) - India | Data. Statista Research Department. https://data.worldbank.org/indicator/SL.UEM.ADVN.ZS?locations=IN

Statista Research Department. (2021). • India - unemployment rate by education level 2019 | Statista. Statista Research Department. https://www.statista.com/statistics/1001039/india-unemployment-rate-by-educationlevel/

Tsamadias, C., \& Prontzas, P. (2012a). The effect of education on economic growth in Greece over the 1960-2000 period. Education Economics, 20(5), 522-537. https://doi.org/10.1080/09645292.2011.557906

Tsamadias, C., \& Prontzas, P. (2012b). Why empathy is an elearning superpower. Education Economics, 20(5), 522-537.

UIA. (1997). Underutilization of human resources | World Problems \& Global Issues | The Encyclopedia of World Problems. The Encyclopedia of World Problems \& Human Potential. http://encyclopedia.uia.org/en/problem/137000

Viswanath, J., Reddy, K. L. N., Pandit, V., Viswanath, J., Reddy, K. L. N., \& Pandit, V. (2017). Human Capital Contributions to Economic Growth in India: An Aggregate Production Function Analysis Published by: Shri Ram Centre for Industrial Relations and Human Resources Linked references are available on JSTOR for this article: Human Capital Contr. 44(3), 473-486.

World Bank. (2020). Human Capital Index 2020 -India (Issue October). https://databank.worldbank.org/data/download/hci/HCI_2pager_IND.pdf?cid=GGH_e_h cpexternal_en_ext

World Bank. (2021). GDP growth (annual \%) - India | Data. https://data.worldbank.org/indicator/NY.GDP.MKTP.KD.ZG?end=2020\&locations=IN 
\&start $=1991$

world bank group. (2020). Covid-19 and Human Capital. 